УдК 616.314.17-008.1:616.018.53:612117

DOI 10.11603/2311-9624.2019.2.10399

CYu. L. Bandrivsky

I. Horbachevsky Ternopil National Medical University

bandrivsky@tdmu.edu.ua

\title{
Changes of basic hematological parameters in patients with generalized periodontitis depending on the blood group
}

Summary. General clinical blood test is widely used as one of the most important methods of examination in most diseases. The cellular composition of the blood of a healthy person is fairly constant, so various changes occurring in diseases may have important diagnostic value.

The aim of the study - to analyze changes in the main hematological parameters in patients with generalized periodontitis associated with blood group.

Materials and Methods. The studies were conducted in the clinic of Ternopil State Medical University and Ternopil Regional Blood Transfusion Station. 855 males aged 20-55 years were examined, who were divided into 2 groups: the main group consisted of 570 patients with generalized periodontitis of I - III severity. Complete blood count was determined using an automatic hematology analyzer "Sysmex KH - 21". The morphological study of blood cells was performed using a Zeiss light microscope using a unified method. The erythrocyte sedimentation rate was determined using a Panchenkov unified micromethod.

Results and Discussion. It was found that in patients with generalized periodontitis, a significant decrease in blood was determined: the number of red blood cells (by $17.53 \%$ ) and their volume (by $13.40 \%$ ), p $<0.01$. At the same time, hemoglobin decreased by $25.59 \%$, hematocrit - by $32.18 \%$ against an increase in ESR by 2.7 times, $\mathrm{p}<0.01$, relative to the corresponding data in the comparison group without periodontal pathology. At the same time, it was found that in patients with generalized periodontitis the number of leukocytes increased (by $52.87 \%$ ), neutrophils (by $25.47 \%$ ), p <0.01, stab (by 39.48\%), segmented (by 18.32 \%) leukocytes, $\mathrm{p}<0.05$, relative to the corresponding parameters in the comparison group. At the same time, in patients with generalized periodontitis, the leukocyte index of intoxication was 2.9 times higher than in the examined group of comparison. It should be noted that in patients with generalized periodontitis, depending on the group membership of the blood, the dynamics of the values of the parameters studied was similar to the average, differed depending on the group membership, between the digital tannins.

Conclusions. Our studies allowed us to obtain a block of new data revealing the biological variability of the cellular and molecular composition of blood, to identify features associated with blood group in patients with generalized periodontitis.

Key words: generalized periodontitis; blood group; hematological parameters.

\section{(СЮ. Л. Бандрівський}

Тернопільський національний медичний університет імені І. Я. Горбачевського

\section{Зміни основних гематологічних показників у пацієнтів із генералізованим пародонтитом залежно від групи крові}

Резюме. Загальний клінічний аналіз крові широко використовують як один із найважливіших методів діагностики при більшості захворювань. Клітинний склад крові здорової людини є стабільним, тому різні зміни, що виникають при хворобах, можуть мати важливе діагностичне значення.

Мета дослідження - проаналізувати зміни основних гематологічних показників у хворих на генералізований пародонтит залежно від групи крові.

Матеріали і методи. Дослідження проводили на базі дВНЗ «Тернопільський державний медичний університет імені І. Я. Горбачевського» та на базі Тернопільської обласної станції переливання крові. Обстежено 855 чоловіків у віці 20-55 років, яких поділили на 2 групи: основну групу склали 570 пацієнтів із генералізованим пародонтитом I-III ступенів тяжкості, групу порівняння - 285 осіб без захворювань тканин пародонта. Загальний аналіз крові проводили за допомогою автоматичного гематологічного аналізатора «Sysmex KH-21». Морфологічне дослідження клітин крові виконували за допомогою світлового мікроскопа «Zeiss» із використанням уніфікованого методу. Швидкість осідання еритроцитів визначали за допомогою уніфікованого мікрометоду Панченкова. Статистичну обробку результатів досліджень здійснювали за допомогою загальноприйнятих методів варіаційної статистики. 
Результати досліджень та їх обговорення. Встановлено, що тільки у представників O (I) та А (II) груп крові, хворих на генералізований пародонтит, кількісний вміст RBC у крові був нижче референтних значень. Максимальне зниження середнього об’єму еритроцитів визначали у пацієнтів із ГП з В (III) та AB (IV) групами крові - на 17,75 та 14,55 \% відповідно, p<0,01. У хворих на генералізований пародонтит з A (II) та O (I) групами крові, з основної групи зниження значень проаналізованого параметра було дещо меншим стосовно даних осіб з порівняльної групи з ідентичною груповою належністю крові - на 11,50 та 9,79 \% відповідно, p<0,01. Найменше зменшення вмісту гемоглобіну в крові досліджували у хворих на ГП з А (II) групою крові - на 24,67 \% стосовно даних у практично здорових осіб з ідентичною груповою належністю крові, p<0,01. Необхідно зауважити, що у пацієнтів із ГП, значення проаналізованого показника були нижче референтних даних, незалежно від групової належності крові. Найбільше зниження гематокриту - на 33,80 та 32,69 \%, p<0,01 - визначали у пацієнтів із ГП з А (II) та AB (IV) групами крові, хворих на генералізований пародонтит.

Висновки. Наші дослідження дозволили отримати блок нових даних, що виявляють біологічну мінливість клітинного і молекулярного складу крові, виявити особливості, пов’язані з групою крові у пацієнтів із генералізованим пародонтитом.

ключові слова: генералізований пародонтит; група крові; гематологічний показник.

\section{(СЮ. Л. Бандривский}

Тернопольский национальный медицинский университет имени И. Я. Горбачевского

\section{Изменения основных гематологических показателей у пациентов с генерализованным пародонтитом в зависимости от групшы крови}

Резюме. Общий клинический анализ крови широко используется как один из важнейших методов диагностики при большинстве заболеваний. Клеточный состав крови здорового человека является достаточно постоянным, поэтому различные изменения, возникающие при заболеваниях, могут иметь важное диагностическое значение.

Цель исследования - проанализировать изменения основных гематологических показателей у больных генерализованным пародонтитом в зависимости от группы крови.

Материалы и методы. Исследования проводились на базе ГВУЗ «Тернопольский государственный медицинский университет имени И. Я. Горбачевского» и на базе Тернопольской областной станции переливания крови. Обследовано 855 мужчин в возрасте 20-55 лет, которых разделили на 2 группы: основную группу составили 570 пациентов с генерализованным пародонтитом I-III степеней тяжести, группу сравнения - 285 лиц без заболеваний тканей пародонта. Общий анализ крови проводили с помощью автоматического гематологического анализатора «Sysmex KH-21». Морфологическое исследование клеток крови проводили с помощью светового микроскопа «Zeiss» с использованием унифицированного метода. Скорость оседания эритроцитов определяли с помощью унифицированного микрометода Панченкова. Статистическую обработку результатов исследований осуществляли с помощью общепринятых методов вариационной статистики.

Результаты исследований и их обсуждение. Установлено, что только у представителей O (I) и А (II) групп крови, больных генерализированным пародонтитом, количественное содержание RBC в крови был ниже референтных значений. Максимальное снижение среднего объема эритроцитов определяли у больных ГП с В (III) и АВ (IV) группами крови - на 17,75 и 14,55 \% соответственно, р<0,01. У больных генерализованным пародонтитом с А (II) и В (I) группами крови основной группы снижение значений проанализированного параметра было несколько меньше относительно данных у лиц сравнительной группы с идентичной групповой принадлежностью крови - на 11,50 и 9,79 \% соответственно, p<0,01. Наименьшее снижение содержания гемоглобина в крови исследовали у больных ГП с A (II) группой крови - на 24,67 \% относительно данных у практически здоровых лиц с идентичной групповой принадлежностью крови, р<0,01. Следует заметить, что у пациентов с ГП, значение проанализированного показателя были ниже референтных данных, независимо от групповой принадлежности крови. Наибольшее снижение гематокрита - на 33,80 и 32,69 \%, p<0,01 - определяли у пациентов с ГП с А (II) и АВ (IV) группами крови, больных генерализованным пародонтитом.

Выводы. Наши исследования позволили получить блок новых данных, проявляющих биологическую изменчивость клеточного и молекулярного состава крови, выявить особенности, связанные с группой крови у пациентов с генерализованным пародонтитом.

Ключевые слова: генерализованный пародонтит; группы крови; гематологический показатель. 
Blood is the main component of the liquid internal environment of the body, its cellular and molecular composition performs many functions [1-4]. A well-known fact is the heterogeneous cellular composition of blood in individuals of different sex and age, which is usually associated with a pronounced effect on the hematopoiesis of immunocompetent hormone cells produced by the sex glands [2, 5, 6]. Of the blood cells, red blood cells carry a sign of group affiliation, which has clinical significance in transfusiology and plays a role in the realization of reproductive function, resistance, or contributing to the occurrence of diseases of infectious or non-infectious etiology. Blood group affiliation is a system of balanced polymorphism, a means of increasing the adaptive capacity of a population, resistance to diseases and to adverse environmental factors [2, 7, 8].

Blood plasma is a natural extracellular environment with respect to blood cells. It, interacting with an individual unique topographic set of glycolipoproteins of the cytoplasmic membranes of each of the cell populations, can influence their physicochemical properties [9-11]. Determining not only the functional abilities to perform receptor, regulatory, transport function, intermolecular interaction, but also affects such integral visual parameters as cell volume and shape. All this is the result of a combination of endogenous structural and metabolic properties of blood cells and exogenous parameters of blood plasma [5, 9, 12].

General clinical blood analysis is widely used as one of the most important methods of examination for most diseases, and in the diagnosis of diseases of the hematopoietic system - it plays a leading role [12-14]. Changes in the blood are most often non-specific, but at the same time reflect the dynamics of the whole organism. The cellular composition of the blood of a healthy person is fairly constant, so various changes occurring in diseases may have important diagnostic value [1, $3,10,15]$.

In the literature available to us, we did not find data on the relationship of blood groups with a tendency to dystrophic-inflammatory diseases of periodontal tissues, group-specific, metabolic features, as platforms for the pathogenesis of generalized periodontitis, have not been studied [16-18]. Therefore, the establishment of associated relationships between metabolic, cytometric characteristics and antigens of $\mathrm{AB} 0$ will help to identify the group at increased risk of developing generalized periodontitis, find out its polymorphism, that is, identify groups with features of the disease and find out a combination of various forms of pathology.

The aim of the study - to analyze changes in the main hematological parameters in patients with generalized periodontitis associated with blood group.

Material and methods. The studies were conducted in the clinic of Ternopil State Medical University and Ternopil Regional Blood Transfusion Station. 855 males aged 20-55 years old were examined, who were divided into 2 groups: the main group consisted of 570 patients with generalized periodontitis of I-III severity; the comparative group included 285 healthy individuals. Patients in both groups of studies were somatically healthy, which was confirmed by the absence of complaints, physical examination data and the absence of non-communicable and infectious diseases according to outpatient records. The diagnosis of periodontal tissue diseases was established according to the classification of N. F. Danilevsky [19, 20].

Complete blood count was determined using an automatic hematology analyzer «Sysmex KH 21" by Roche (Japan) using a commercial reagent kit by Roche (Germany). The morphological study of blood cells was carried out using a Zeiss light microscope using a unified method, the principle of which is microscopy of stained blood smears with the differentiation of various forms of white blood cells. The erythrocyte sedimentation rate was determined using Panchenkov unified micromethod [12, 13, 21]. On the basis of the data obtained from "white blood" in patients of the study groups, we calculated the simplified leukocyte intoxication index (LII) for I.I. Kalf-Kaifa (1950) in the modification of E.I. Syromyatnikova (1997).

Results and discussion. Our studies allowed us to obtain a block of data revealing the biological variability of the cellular and molecular composition of blood and in the oral fluid of patients with generalized periodontitis associated with blood groups.

Red blood cells (RBC) - the most numerous blood cells containing hemoglobin transport oxygen and carbon dioxide and are formed from reticulocytes when they leave the bone marrow. Reference values - 4.2-5.6 $\times 10^{12} / 1$ [9, 22, 23].

The average quantitative composition of erythrocytes (Table 1) in the blood of people with intact periodontium was $17.53 \%$ higher compared to similar values in individuals with generalized periodontitis (GP) $(4.85 \pm 0.07) \times 10^{12}$ 
l. relative to $(4.00 \pm 0.05) \times 10^{12} / 1$., respectively, $\mathrm{p}$ $<0.01$ ). The maximum reduction in the number of erythrocytes in the blood was investigated in carriers of A (II) and O (I) blood groups, with GP by $19.63 \%$ and by $18.93 \%$, respectively, $\mathrm{p}<0.01$. Somewhat less, but statistically significant, was a decrease in the values of the analyzed parameter in patients with GP with AB (IV) and B (III) blood groups: by $17.86 \%$ and $13.84 \%$, respectively, $\mathrm{p}$ $<0.01$. It was noted that only representatives of the $\mathrm{O}$ (I) and A (II) blood groups, with generalized periodontitis, the quantitative content of RBC in the blood was lower than the reference values.

The average volume of erythrocytes in practically healthy people exceeded, on average, similar values in patients with GP by $13.40 \%(87.19 \pm 0.87)$ fl. relative to $(75.51 \pm 1.99)$ fl., respectively, $\mathrm{p}<0.01)$. It was noted that in patients with GP, regardless of the blood group, the average red blood cell volume was less than the reference norm (84-87 fl.). At the same time, the maximum decrease in the average volume of erythrocytes was determined in patients with GP with B (III) and AB (IV) blood groups - by 17.75 $\%$ and $14.55 \%$, respectively, $\mathrm{p}<0.01$. In patients of the main group, with generalized periodontitis with A (II) and B (III) blood group, the decrease in the values of the analyzed parameter was slightly less compared with the data in the comparative group with identical blood group - by $11.50 \%$ and $9.79 \%$ respectively, $\mathrm{p}<0.01$.

Hemoglobin $(\mathrm{Hb})$ - the main component of erythrocytes, is a complex protein consisting of heme (iron-containing part of $\mathrm{Hb}$ ) and globin (protein part of $\mathrm{Hb}$ ). The main function of hemoglobin is the transfer of oxygen from the lungs to the tissues, as well as the removal of carbon dioxide $\left(\mathrm{CO}_{2}\right)$ from the body and the regulation of the acid-base state. Reference hemoglobin values are 131-172 g/l [7, 24].

In people of the comparative group, the average hemoglobin content in the blood was $25.59 \%$ higher compared to the mean values in individuals with GP $(142.23 \pm 2.33) \mathrm{g} / \mathrm{l}$ relative to $(105.83 \pm 1.85)$ $\mathrm{g} / \mathrm{l}$, respectively, $\mathrm{p}<0.01$ ). The maximum decrease in hemoglobin in the blood was determined in carriers of $\mathrm{AB}$ (IV) blood groups with GP - by $26.56 \%, \mathrm{p}<0.01$. In patients with generalized periodontitis with a $\mathrm{B}$ (III) and $\mathrm{O}$ (I) blood group, the decrease in the values of the analyzed parameter was the same, on average, by $25.51 \%$ compared to the data in the comparison group, $\mathrm{p}<0.01$. The smallest decrease in hemoglobin in the blood was studied in patients with GP with A (II) blood group - by $24.67 \%$ compared to data from practically healthy individuals with identical blood group, $\mathrm{p}<0.01$. It should be noted that in patients with GP, the value of the analyzed index was lower than the reference data, regardless of the blood group.

Hematocrit shows the ratio of plasma volume and blood cells. Reference hematocrit values are $44-48 \%[9,25]$. In practically healthy people of the comparative group, the percentage composition of hematocrit was on average $32.18 \%$ higher than

Table 1. The value of hematological parameters in the serum of individuals of study, depending on the group of blood

\begin{tabular}{|c|c|c|c|c|c|c|c|c|}
\hline \multirow{2}{*}{$\begin{array}{l}\text { Hematologic } \\
\text { indicators }\end{array}$} & \multicolumn{4}{|c|}{ Main group $(n=570)$} & \multicolumn{4}{|c|}{ Comparative group $(\mathrm{n}=285)$} \\
\hline & 0 (I) & A (II) & B (III) & $\mathrm{AB}(\mathrm{IV})$ & 0 (I) & A (II) & B (III) & $\mathrm{AB}(\mathrm{IV})$ \\
\hline $\begin{array}{l}\text { Red blood } \\
\text { cell count } \\
\left(\times 10^{12} / \mathrm{l}\right) \\
\end{array}$ & $\begin{array}{l}3.94 \pm \\
0.06^{*}\end{array}$ & $\begin{array}{l}3.89 \pm \\
0.07^{*}\end{array}$ & $\begin{array}{l}4.17 \pm \\
0.03^{*}\end{array}$ & $\begin{array}{l}4.00 \pm \\
0.05^{*}\end{array}$ & $\begin{array}{c}4.86 \pm \\
0.09\end{array}$ & $\begin{array}{l}4.84 \pm \\
0.06\end{array}$ & $\begin{array}{c}4.84 \pm \\
0.06\end{array}$ & $\begin{array}{l}4.85 \pm \\
0.07\end{array}$ \\
\hline $\begin{array}{l}\text { Hematocrit } \\
(\%)\end{array}$ & $\begin{array}{l}30.70 \pm \\
0.70^{*}\end{array}$ & $\begin{array}{c}29.48 \pm \\
0.81^{*}\end{array}$ & $\begin{array}{l}30.24 \pm \\
0.71^{* *}\end{array}$ & $\begin{array}{c}30.14 \pm \\
0.76^{*}\end{array}$ & $\begin{array}{c}44.31 \pm \\
0.77\end{array}$ & $\begin{array}{c}44.53 \pm \\
0.56\end{array}$ & $\begin{array}{c}44.18 \pm \\
0.56\end{array}$ & $\begin{array}{c}44.44 \pm \\
0.61\end{array}$ \\
\hline $\begin{array}{l}\text { The average } \\
\text { volume of } \\
\text { red blood } \\
\text { cells (fl) }\end{array}$ & $\begin{array}{c}78.66 \pm \\
2.09 *\end{array}$ & $\begin{array}{c}76.64 \pm \\
1.75^{*}\end{array}$ & $\begin{array}{c}71.73 \pm \\
2.08^{*}\end{array}$ & $\begin{array}{c}75.51 \pm \\
1.99 *\end{array}$ & $\begin{array}{c}87.15 \pm \\
0.67\end{array}$ & $\begin{array}{c}86.60 \pm \\
0.63\end{array}$ & $87.21 \pm 0.68$ & $\begin{array}{c}87.19 \pm \\
0.87\end{array}$ \\
\hline $\begin{array}{l}\text { Hemoglobin } \\
(\mathrm{g} / \mathrm{l})\end{array}$ & $\begin{array}{c}106.41 \pm \\
1.31^{*}\end{array}$ & $\begin{array}{c}105.89 \pm \\
1.92^{*}\end{array}$ & $\begin{array}{c}106.51 \pm \\
1.60^{*}\end{array}$ & $\begin{array}{c}105.83 \pm \\
1.85 *\end{array}$ & $\begin{array}{c}142.55 \pm \\
3.02\end{array}$ & $\begin{array}{c}140.57 \pm \\
1.51\end{array}$ & $\begin{array}{c}143.49 \pm \\
1.60\end{array}$ & $\begin{array}{c}142.23 \pm \\
2.33\end{array}$ \\
\hline $\begin{array}{l}\text { ESR } \\
\text { (mm / hour) }\end{array}$ & $\begin{array}{l}11.95 \pm \\
2.60^{*}\end{array}$ & $\begin{array}{c}10.96 \pm \\
1.94^{*}\end{array}$ & $\begin{array}{l}8.51 \pm \\
1.49^{* *}\end{array}$ & $\begin{array}{l}9.98 \pm \\
1.20^{*}\end{array}$ & $\begin{array}{c}3.83 \pm \\
0.47\end{array}$ & $\begin{array}{l}4.72 \pm \\
0.62\end{array}$ & $\begin{array}{c}2.94 \pm \\
0.38\end{array}$ & $\begin{array}{c}3.74 \pm \\
0.48\end{array}$ \\
\hline
\end{tabular}

Note. ${ }^{*}-\mathrm{p}<0.01 ;{ }^{* *}-\mathrm{p}<0.05$ - significant difference of values relative to the data of the comparative group. 
the corresponding value in patients of the main group $(44.44 \pm 0.61) \%$ relative to $(30.14 \pm 0.76) \%$, respectively, $\mathrm{p}<0.01$ ). The greatest decrease in hematocrit - by $33.80 \%$ and by $32.69 \%$, p $<0.01$ was determined in patients with GP with A (II) and $A B$ (IV) blood groups of patients with generalized periodontitis. Somewhat less was the decrease in the analyzed parameter in patients with GP with B (III) and O (I) blood group - by $31.65 \%$, p < $<.05$, and by $30.72 \%, p<0.01$, relative to values in group of comparison `s.

Erythrocyte sedimentation rate (ESR) is an indicator of the rate of blood separation in a test tube with the addition of an anticoagulant into 2 layers: upper (transparent plasma) and lower (erythrocytes). The erythrocyte sedimentation rate is estimated from the height of the plasma layer (in $\mathrm{mm}$ ) formed over 1:00. The specific mass of erythrocytes is higher than the specific mass of plasma, therefore in a test tube in the presence of an anticoagulant, under the action of gravity, erythrocytes settle to the bottom. The speed with which erythrocyte sedimentation occurs is mainly determined by the degree of their aggregation, that is, their ability to stick together. Erythrocyte aggregation mainly depends on their electrical properties and protein composition of blood plasma. Normally, red blood cells carry a negative charge (zeta potential) and repel each other. The degree of aggregation, and hence the ESR increases with the increase in plasma of proteins of the acute phase - fibrinogen, C-reactive protein, ceruplasmin, immunoglobulins. At the same time, ESR decreases with an increase in albumin, lipids, when the blood $\mathrm{Ph}$ is shifted to the acid side, blood viscosity. The number, shape and size of red blood cells also affect precipitation. Reducing the content of red blood cells leads to an accelerated ESR. Reference values of ESR - 2-10 mm/hour [12].

In our study, in practically healthy individuals of the comparative group, the ESR was 2.7 times lower than the data in patients of the main group $(3.74 \pm 0.48) \mathrm{mm} / \mathrm{h}$ relative to $(9.98 \pm 1.20)$ $\mathrm{mm} / \mathrm{h}$, respectively, $\mathrm{p}<0.01)$. ESR in carriers of 0 (I) and B (III) blood groups decreased in ABOut the same manner, with GP, by 3.1 and 2.9 times, respectively, $p<0.01$. Somewhat less was the decrease in the analyzed index in $A B$ (IV) carriers - by 2.5 times and A (II) - by 2.3 times, $p<0.01$ blood groups.

Leukocytes (white blood cells, WBC) are blood cells whose main function is to protect the body against foreign agents (toxins, viruses, bacteria, dying cells of its own organism, etc.). The formation of leukocytes (leukopoesis) takes place in the bone marrow and lymph nodes. The number of leukocytes in the circulating blood is an important diagnostic indicator, which depends on the rate of inflow of cells from the bone marrow and the rate of their release into the tissues. Reference values of leukocytes in the blood $-4.0-8.8 \times 10^{9}$ [1].

In practically healthy individuals of the comparative group, the number of leukocytes in the blood was on average $52.87 \%$ lower compared to similar values in GP patients $(6.28 \pm 0.37) \times 10^{9} / 1$ relative to $(9.60 \pm 0.55) \times 10^{9} / 1$, accordingly, $\left.\mathrm{p}<0.01\right)$. At the same time, in patients with GP, carriers of 0 (I) and $\mathrm{AB}$ (IV) blood groups, the quantitative composition of leukocytes in the blood increased equally, on average by $55.68 \%, p<0.01$. In representatives of A (II) and B (III) blood groups, the increase in leukocyte count in the blood was slightly less and increased on average by $50.35 \%$ compared with the data in people in the comparative group with identical blood group, $\mathrm{p}<0.01$ (Table 2).

Leukogram (Differential White Blood Cell Count, ) is the percentage of different types of white blood cells. According to morphological features (type of nucleus, presence and nature of cytoplasm inclusions), 5 main types of leukocytes (neutrophils, lymphocytes, monocytes, eosinophils, basophils) are isolated. Most of the precursor cells of mature leukocytes (metamyelocytes, myelocytes, promyelocytes, blastocytes), as well as plasma cells, young nuclear cells of the erythroid series and others, appear in peripheral blood only in the case of pathology. Different types of leukocytes perform different functions, therefore the determination of the ratio of different types of leukocytes, the maintenance of young forms, the identification of pathological cellular forms, the description of characteristic changes in cell morphology, reflecting changes in functional activity, carry valuable diagnostic information. At the same time, changes in leukocyte formula are not specific - they may have a similar character in various diseases or, on the contrary, unlike changes may occur in the same pathology in different patients $[1,3,26]$.

Neutrophils are the most numerous type of white blood cells, which make up 50-75\% of all white blood cells. Depending on the degree of maturity and the shape of the nucleus in the peripheral blood, segmented (mature) and relatively small number of band (younger) neutrophils are isolated. The main function of neutrophils is to protect the body against infections, which is 
Table 2. The value of indicators of leukocyte link in the serum of individuals of study groups, depending on the group of blood

\begin{tabular}{|c|c|c|c|c|c|c|c|c|}
\hline \multirow{2}{*}{$\begin{array}{l}\text { Hematologic } \\
\text { indicators }\end{array}$} & \multicolumn{4}{|c|}{ Main group (n= 570) } & \multicolumn{4}{|c|}{ Comparative group $(n=285)$} \\
\hline & 0 (I) & A (II) & B (III) & $\mathrm{AB}$ (IV) & 0 (I) & A (II) & B (III) & AB (IV) \\
\hline $\begin{array}{l}\text { Leukocyte } \\
\text { count } \\
\left(\times 10^{9} / 1\right)\end{array}$ & $\begin{array}{l}9.60 \pm \\
0.41^{*}\end{array}$ & $\begin{array}{l}9.76 \pm \\
0.33^{*}\end{array}$ & $\begin{array}{l}9.44 \pm \\
0.62^{*}\end{array}$ & $\begin{array}{l}9.60 \pm \\
0.55^{*}\end{array}$ & $\begin{array}{c}6.15 \pm \\
0.28\end{array}$ & $\begin{array}{l}6.45 \pm \\
0.30\end{array}$ & $\begin{array}{l}6.32 \pm \\
0.35\end{array}$ & $\begin{array}{c}6.28 \pm \\
0.37\end{array}$ \\
\hline $\begin{array}{l}\text { Neutrophil } \\
\text { content (\%) }\end{array}$ & $\begin{array}{c}63.51 \pm \\
3.34^{*}\end{array}$ & $\begin{array}{c}65.42 \pm \\
2.37^{*}\end{array}$ & $\begin{array}{c}62.54 \pm \\
2.59^{*}\end{array}$ & $\begin{array}{c}64.68 \pm \\
2.68^{*}\end{array}$ & $\begin{array}{c}50.70 \pm \\
2.49\end{array}$ & $\begin{array}{c}52.10 \pm \\
2.21\end{array}$ & $\begin{array}{c}50.96 \pm \\
2.64\end{array}$ & $\begin{array}{c}51.58 \pm \\
2.30\end{array}$ \\
\hline $\begin{array}{l}\text { The content } \\
\text { of stab } \\
\text { neutrophils } \\
\text { (\%) }\end{array}$ & $\begin{array}{l}5.93 \pm \\
0.54^{*}\end{array}$ & $\begin{array}{l}3.71 \pm \\
0.53^{*}\end{array}$ & $\begin{array}{c}2.05 \pm \\
0.69^{* *}\end{array}$ & $\begin{array}{c}3.78 \pm \\
0.61^{* *}\end{array}$ & $\begin{array}{l}3.86 \pm \\
0.39\end{array}$ & $\begin{array}{c}1.76 \pm \\
0.35\end{array}$ & $\begin{array}{c}3.73 \pm \\
0.37\end{array}$ & $\begin{array}{c}2.71 \pm \\
0.35\end{array}$ \\
\hline $\begin{array}{l}\text { The } \\
\text { content of } \\
\text { segmented } \\
\text { neutrophils } \\
\text { (\%) }\end{array}$ & $\begin{array}{c}57.58 \pm \\
2.16^{*}\end{array}$ & $\begin{array}{c}61.71 \pm \\
2.19^{*}\end{array}$ & $\begin{array}{l}58.49 \pm \\
3.63^{* *}\end{array}$ & $\begin{array}{l}60.40 \pm \\
2.60^{* *}\end{array}$ & $\begin{array}{c}46.84 \pm \\
2.72\end{array}$ & $\begin{array}{c}50.34 \pm \\
2.87\end{array}$ & $\begin{array}{c}47.23 \pm \\
3.41\end{array}$ & $\begin{array}{l}51.05 \pm \\
3.80\end{array}$ \\
\hline
\end{tabular}

Note. ${ }^{*}-\mathrm{p}<0.01{ }^{* *}-\mathrm{p}<0.05-$ significant difference of values relative to the data of the comparative group.

carried out mainly by phagocytosis [10].

It was established that in the comparative group under study, the content of neutrophils in the blood was lower relative to the value in patients of the main group, on average, by $25.47 \%$ $(52.55 \pm 1.84) \%$ relative to $(64.68 \pm 2.68) \%, \mathrm{p}<0.01)$.

The maximum increase in the neutrophil content in the blood was determined in patients with GP, carriers of AB (IV) blood group (by 27.93 $\%, \mathrm{p}<0.01)$. A minimum increase in the analyzed values was determined of the representatives of the B (III) group blood with this dental disease (in $22.72 \%, p<0.01)$. It was noted that in patients of the main group with $\mathrm{O}$ (I) and A (II) blood group, the content of neutrophils in the blood increased equally, by an average of $25.41 \%$ relative to the data in the comparison groups with identical blood group, $p<0,01$.

The content of stab neutrophils in the blood of the comparative group studied was $39.48 \%$ lower relative to the data in the main group $(2.71 \pm 0.35)$ $\%$ relative to $(3.78 \pm 0.61) \%, p<0.05)$.

The maximum increase in the values of the analyzed indicator was investigated in patients with GP with $\mathrm{AB}$ (IV) and A (II) blood groups - by $128.67 \%, \mathrm{p}<0.05$, and $110.80 \%, \mathrm{p}<0.01$, respectively, relative to data in comparison. The increase in the level of stab neutrophils in the blood of patients of the main group with $\mathrm{O}$ (I) blood group was $53.63 \%, \mathrm{p}<0.01$. At the same time, in patients with generalized periodontitis with B (III) blood group, the value of the analyzed index decreased and was $45.05 \%$ lower compared to the data in the comparison group, $\mathrm{p}<0.05$.

The level of segmented neutrophils in patients with GP on average exceeded the data in comparison by $18.32 \%(60.40 \pm 2.60) \%$ relative to $(51.05 \pm 3.80) \%, p<0.05)$. The increase in the content of segmented neutrophils in patients of the main group with B (III), A (II) and B (I) blood group was almost the same - by $23.84 \%$, $\mathrm{p}<0.05$, by $22.59 \%$, and by $22.93 \%$, p $<0.01$, respectively, relative to similar values in the comparison group. The minimum prevalence of the values of the analyzed indicator was determined in carriers of $\mathrm{AB}$ (IV) blood group of the main group - by $18.04 \%, \mathrm{p}<0.05$, relative to the corresponding data in the comparison group.

Lymphocytes - are the main cellular elements of the immune system, which are formed in the bone marrow and are actively functioning in the lymphoid tissue. The main function of lymphocytes is the recognition of a foreign agent and an adequate immune response of the body. Different subpopulations of lymphocytes perform various functions - provide cellular immunity (in particular transplant rejection, destruction of tumor cells), humoral response (in the form of antibody synthesis to foreign cells), as well as immune memory (the body's ability to accelerate, strengthen the immune response when it meets again alien agent). In adults, the number of 
lymphocytes is $20-40 \%$ of the total number of leukocytes [1,22].

In patients with generalized periodontitis, the content of lymphocytes in the blood (Table 3 ) was on average $8.22 \%$ lower compared to similar values in comparison $(31.48 \pm 2.34) \%$ relative to $(34.30 \pm 2.16) \%, p<0.05)$. At the same time, the maximum reduction in the data of the analyzed indicator was determined in carriers of A (II) blood group - by $22.56 \%$, p $<0.01$, and representatives of AB (IV) blood group - by $16.19 \%, p<0.05$, patients with GP. The level of lymphocytes in the blood of representatives of the 0 (I) blood group of the main group decreased slightly by $11.33 \%, p<0.05$, relative to the values in comparison. It was noted that in patients with GP with B (III) blood group, the level of lymphocytes in the blood increased by $18.19 \%, \mathrm{p}<0.05$, relative to data in people of the comparative group with identical blood group.

Eosinophils are present in peripheral blood in a relatively small amount - from 0.5 to $5 \%$ of the total number of leukocytes. And they are activated in the reactions of the organism in case of parasitic, allergic, infectious diseases, when the allergic component is included in the pathogenesis of the disease. Evaluation of the dynamics of changes in the number of eosinophils during the inflammatory process has a prognostic value. Eosinopenia is often observed at the beginning of inflammation, and eosinophilia corresponds to the beginning of recovery [2, 17, 27].

However, a number of diseases are characterized by eosinophilia after the end of the inflammatory process, which indicates the incompleteness of the immune reaction with its allergic component.

In our study, the average eosinophil content in the blood of patients with generalized periodontitis was $53.45 \%$ lower than the corresponding values in the comparison group $(1.28 \pm 0.77) \%$ relative to $(2.75 \pm 0.54) \%, p<0.05)$. The maximum decrease in the content of eosinophils in the blood was determined in 0 (I) representatives - by $62.90 \%$ and $A B(I V)$ - by 52.13 \%blood groups, $\mathrm{p}<0.05$. Somewhat less was the decrease in the level of the analyzed parameter in A (II) and AB (IV) carriers of the blood group - by $50.98 \%$, and by $46.07 \%$, $\mathrm{p}<0.05$, respectively.

Basophils are a small population of white blood cells whose main function is to participate in an anaphylactic reaction of an immediate type of hypersensitivity. They also participate in delayed-type reactions through lymphocytes, in inflammatory and allergic reactions, in the regulation of vascular wall permeability. Basophils contain such biologically active substances as heparin and histamine[12].

In patients of the main group, the average content of basophils in the blood was 4.5 times higher relative to similar values in comparison $(0.94 \pm 0.19) \%$ relative to $(0.21 \pm 0.07) \%, \mathrm{p}<0.01)$. The most substantive increase in the content of basophils in the blood was studied in patients with GP with A (II) and B (III) blood groups - by

Table 3. The value of indicators of leukocyte level in the serum of in study groups, depending on the group of blood

\begin{tabular}{|c|c|c|c|c|c|c|c|c|}
\hline \multirow{2}{*}{$\begin{array}{l}\text { Hematologic } \\
\text { indicators }\end{array}$} & \multicolumn{4}{|c|}{ Main group $(n=570)$} & \multicolumn{4}{|c|}{ Comparative group $(n=285)$} \\
\hline & 0 (I) & A (II) & B (III) & $\mathrm{AB}(\mathrm{IV})$ & 0 (I) & A (II) & B (III) & $\mathrm{AB}(\mathrm{IV})$ \\
\hline $\begin{array}{l}\text { Lymphocyte } \\
\text { Content } \\
(\%)\end{array}$ & $\begin{array}{l}29.89 \pm \\
1.74^{* *}\end{array}$ & $\begin{array}{c}27.05 \pm \\
1.68^{*}\end{array}$ & $\begin{array}{l}39.57 \pm \\
1.97^{* *}\end{array}$ & $\begin{array}{c}31.48 \pm \\
2.34\end{array}$ & $\begin{array}{c}33.71 \pm \\
0.72\end{array}$ & $\begin{array}{c}34.93 \pm \\
1.91\end{array}$ & $\begin{array}{c}33.48 \pm \\
2.31\end{array}$ & $\begin{array}{c}34.30 \pm \\
2.16\end{array}$ \\
\hline $\begin{array}{l}\text { Eosinophil } \\
\text { content } \\
(\%)\end{array}$ & $\begin{array}{l}1.15 \pm \\
0.38^{* *}\end{array}$ & $\begin{array}{l}1.25 \pm \\
0.61^{* *}\end{array}$ & $\begin{array}{l}1.35 \pm \\
0.50^{* *}\end{array}$ & $\begin{array}{l}1.28 \pm \\
0.41^{* *}\end{array}$ & $\begin{array}{c}3.10 \pm \\
0.60\end{array}$ & $\begin{array}{c}2.55 \pm \\
0.42\end{array}$ & $\begin{array}{c}2.82 \pm \\
0.42\end{array}$ & $\begin{array}{c}2.75 \pm \\
0.54\end{array}$ \\
\hline $\begin{array}{l}\text { Basophil } \\
\text { content } \\
(\%) \\
\end{array}$ & $\begin{array}{c}0.83 \pm \\
0.15\end{array}$ & $\begin{array}{l}1.16 \pm \\
0.14^{*}\end{array}$ & $\begin{array}{l}1.07 \pm \\
0.59^{* *}\end{array}$ & $\begin{array}{c}0.94 \pm \\
0.19^{* *}\end{array}$ & $\begin{array}{c}0.42 \pm \\
0.16\end{array}$ & $\begin{array}{c}0.20 \pm \\
0.06\end{array}$ & $\begin{array}{c}0.22 \pm \\
0.07\end{array}$ & $\begin{array}{c}0.21 \pm \\
0.07\end{array}$ \\
\hline $\begin{array}{l}\text { Monocyte } \\
\text { Content } \\
(\%)\end{array}$ & $\begin{array}{c}7.55 \pm \\
0.80\end{array}$ & $\begin{array}{c}7.30 \pm \\
0.74\end{array}$ & $\begin{array}{c}6.85 \pm \\
0.82\end{array}$ & $\begin{array}{c}6.76 \pm \\
1.23\end{array}$ & $\begin{array}{c}7.00 \pm \\
0.98\end{array}$ & $\begin{array}{c}7.65 \pm \\
0.73\end{array}$ & $\begin{array}{c}7.45 \pm \\
0.77\end{array}$ & $\begin{array}{c}7.19 \pm \\
0.89\end{array}$ \\
\hline
\end{tabular}


$5.8 \%, \mathrm{p}<0.01$, and 4.8 times, $\mathrm{p}<0.05$. In patients of the main group with 0 (I) blood group, the level of basophils in the blood increased 2.0 times, $\mathrm{p}<0.05$. In patients with GP, carriers of $\mathrm{AB}$ (IV) blood group, the level of the analyzed parameter in the blood was $(0.70 \pm 0.39) \%$ in the absence of this cellular component in the reference group under study.

Monocytes - large cells among leukocytes, belong to the system of phagocytic mononuclear cells which play an important role in the processes of phagocytosis. In the focus of inflammation, monocytes phagocytize microbes and leukocytes, as well as damaged cells of the inflamed tissue, clearing the focus of foliation and preparing it for regeneration[10]. On average, the concentration of monocytes in the blood of the subjects was the same $-(7.12 \pm 0.89) \%$ and $(7.19 \pm 0.89) \%$ in the main and comparative groups, respectively, $p>0.05$. It was noted that the content of monocytes in the blood of patients with GP with different blood group affiliation did not differ in statistical significance from the data in the comparison group, $\mathrm{p}<0.05$.

As a result of the conducted research, it was established (figure 1) that, in patients with GP, on average, leukocyte intoxication index was 2.9 times higher than the data in the comparative group (1.38 \pm 0.42$)$ points versus $(0.48 \pm 0.19)$ points, accordingly, $p>0.05$ ). The maximum increase in the data of the studied index was determined in representatives of the $\mathrm{O}$ (I) and A (II) blood groups of the main group, which were 3.7 and 3.2 times higher than the relatively similar values in the comparison group, $\mathrm{p}<0.01$. The values of leukocyte intoxication index in patients with HP with $\mathrm{AB}$ (IV) and $\mathrm{B}$ (III) blood groups increased slightly by a factor of $2.9, \mathrm{p}<0.01$ and 2.1 times, $\mathrm{p}<$ 0.05 , respectively.

Thus, in patients with GP, phenomena of

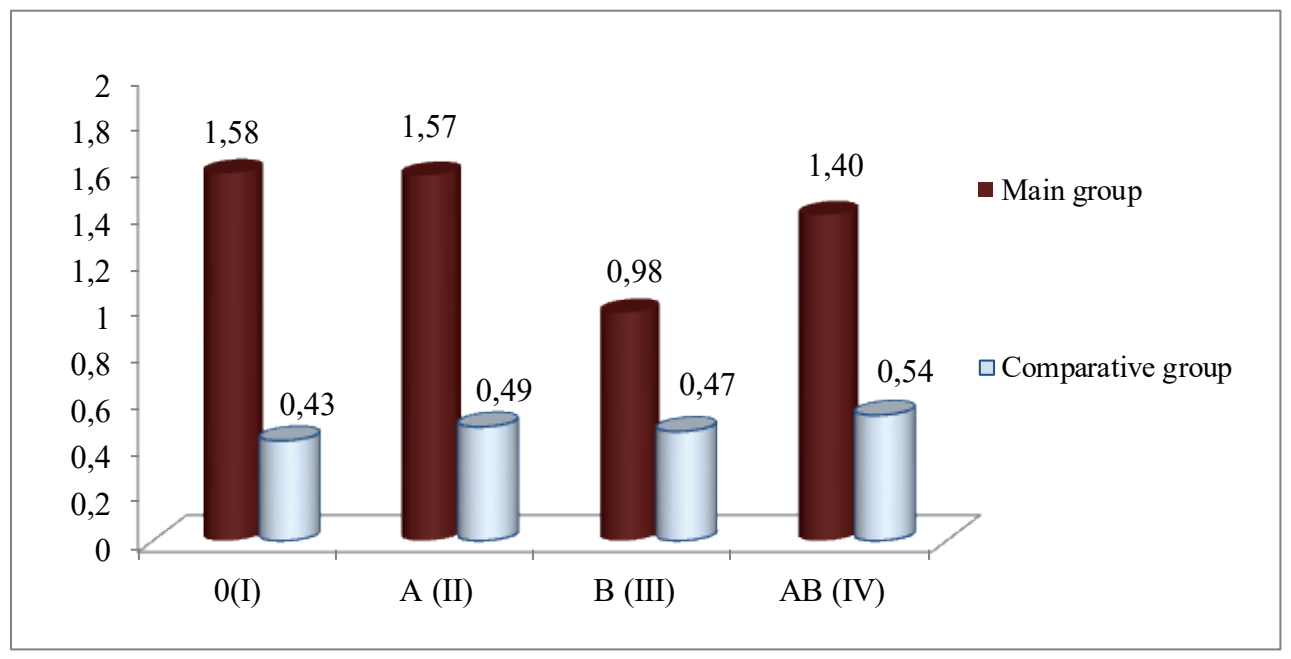

Figure 1. Leukocyte intoxication index value in patients of study groups.

endogenous intoxication can be traced, which is on a scale of I. N. Bolshakov (1991) corresponds to mild severity and is probably caused by impaired metabolism, membrane barrier functions, regulatory systems, excessive presence of inflammatory mediators, microbial toxins of immunopacies [26, 28, 29].

Results and Discussion. A data block was obtained that reveals the peculiarities of blood cell composition (red blood cell count, average red blood cell volume, red blood cell size distribution, hemoglobin content, concentration and average hemoglobin content in the red blood cell, hematocrit, absolute and relative content of various leukocyte forms) in patients on generalized periodontitis with a different blood groups.

Conclusion. Thus, there were identified individually group features, the nature of their fluctuations can be regarded as predictors of certain pathological processes and in many ways contribute to the improvement of diagnoses dystrophic inflammatory processes in periodontal tissues. 


\section{Lift of Literature}

1. Алмазов В. А. Фізіологія лейкоцитов человека /

В. А. Алмазов. - Ленинград, 1979. - 150 с.

2. Бандрівський Ю. Л. Взаємозв’язок групової і резус приналежності крові з інфекційними та неінфекційними захворюваннями / Ю. Л. Бандрівський // Молодий вчений. - 2017. - № 2 (42). - С. 23-27.

3. Шифман Ф. Д. Патофизиология крови / Ф. Д. Шифман. - СПб., 2001. - 445 с.

4. Neil D. A. The Rh blood group system: a review / D. A. Neil, M. E. Reid // Blood. - 2000. - Vol. 15. - P. 375-387. 5. Oguchi Y. The nature of human blood group A3 erythrocytes / Y. Oguchi // Vox. Sang. - 2017. - Vol. 34. - P. 32-47.

6. Yamamoto F. Molecular genetic of the AB0 histoblood group system / F. Yamamoto // Vox. Sang. - 1995. Vol. 69. - P. 1-7.

7. Blood groups classification / G. L. Daniels, D. J. Anstee, J. P. Carton [et al.] // Vox. Sang. - 2005. - Vol. 69, No. 4. P. 265-279.

8. Schenkel-Bruner H. Human blood groups. Chemical and biochemical basis of antigen specificity. New York, 2000. - P. 30-293.

9. Anstee D. J. Blood-group active surface molecules of the human red blood cell / D. J. Anstee // Vox. Sang. 2013. - Vol. 58. - P. 1-20

10. Ferreira H. G. Membrane transport in red cell / H. G. Ferreira, V. L. Lew. - Acad. press. - 2012. - P. 53-92. 11. Blood groups classification/G. L. Daniels, D. J. Anstee, J. P. Carton [et al.] // Vox Sang. - 1995. - Vol. 69 (4). - P. 265-279.

12. Меншиков. В. В. Клиническая лабораторная аналитика / В. В. Меншиков. - М. : Агат-Мед., 2002. $-860 \mathrm{c}$.

13. Карпищенко А. И. Медицинские лабораторние технологии / А. И. Карпищенко. - М. : Геотар-Медиа, 2013. - 792 c.

14. Genomic cloning of the human histo-blood group AB0 locus / E. Bennet, R. Steffensen, H. Clausen [et al.] // Biochem. Biophys. Res. Commun. - 1995. - Vol. 206. P. 318-325.

15. Indicators of markers of bone metabolism in patients with generalized periodontitis depending on blood group affiliation: original paper / Yu. Bandrivsky, O. Bandrivska, R. Gnid [et al.] // Arch. Balk Med. Union. 2019. - Vol. 54 (1). - P. 11-16.

16. Антонова Т. В. Значение некоторых гематоло-

\section{References}

1. Almazov, V.A. (1979). Fiziologiya leykotsitov cheloveka [Human leukocyte physiology]. Leningrad [in Russian]. 2.Bandrivskyi, Yu.L. (2017). Vzaiemozviazok hrupovoi i rezus-prynalezhnosti krovi z infektsiinymy ta neinfektsiinymy zakhvoriuvanniamy [The interrelationship of group and rhesus accessory blood with infectious and non-communicable diseases]. Molodyi vchenyi - Young Scientist, 2 (42), 23-27 [in Ukrainian]

3. Shiffman, F.D. (2001). Patofiziologiya krovi [Pathophysiology of blood]. Saint-Petersburg [in Russian].

4. Neil, D.A., \& Reid, M.E. (2000). The Rh blood group system: a review. Blood. 15, 375-387. гических параметров при острых одонтогенных воспалительных заболеваниях челюстей / Т. В. Антонова, С. Л. Николаєнко, Д. А. Лианозов // Клиническая лабораторная диагностика. - 1999. - № 7. - С. 23-24.

17. Тимофеев А. А. Значение некоторых гематологических показателей при при острых одонтогенных воспалительных заболеваниях челюстей / А. А. Тимофеев // Проблемы алергии. - 2009. - № 6. - С. 74-75.

18. Stahl S. S. Host resistance and periodontal diseases / S. S. Stahl // J. Dent. Res. - 2010. - Vol. 49 (2). - P. 248-255. 19. Данилевский Н. Ф. Заболевания пародонта / Данилевский Н. Ф. Борисенко А. В. - К. : Медецина. 2000. - 461 c.

20. Борисенко А. В. Терапевтична стоматологія / А. В. Борисенко. - К. : Медицина, 2008. - № 2. - 409 с. 21. Isacov I. Preoperative assessment of patients with inflammatory processes in the maxillo-facial region: a minireview / I. Isacov, S. Levco // Arch. Balk. Med. Union. - 2018. - Vol. 53 (2). - P. 275-280.

22. Palek J. Red blood cell membrane mutations / J. Palek, K. E. Sahr // Blood. - 2015. - Vol. 80 - P. 308-330. 23. Nomura Y. Screening of periodontitis with salivary enzyme test / Y. Nomura, Y. Tanaki, T. Tanaka // J. Oral Sral. Sci. - 2006. - Vol. 12. - P. 177-183.

24. Bolezni parodonta. Patogenez, diagnostika, lecheniye / Grigorian AS, Grudyanov AI, Ryabukhina NA, Frolova OA. - Moscow: MIA. 2004: 287.

25. Fourel J. Periodontosis: a periodontal syndrome / J. Fourel // J. Periodontol. - 1972. - Vol. 43. - P. 240-255. 26. Показатели крови и лейкоцитарного индекса интоксикации в оценки тяжести и опридилении прогноза при воспалительных заболеваниях / В. К. Островский, А. Б. Мащенко, Д. В. Янголенко [и др.] // Клиническая лабораторная диагностика. 2006. - C. 50.

27. Flow cytometric analysis of erythrocyte blood group A antigen density profiles / Z. Bermeman, D. van Bockstaele, W. Uyttenbreek [et al.] // Vox. Sang. - 2013. Vol. 61. - P. 265-274.

28. Tomaszewski T. Assessment of mandible bone structure in patients with generic osteoporosis symptoms / T. Tomaszewski // Annales Universitatis Mariae Curie-Sklodowska. - 2012. - Vol. 57. - P. 329-341. 29. Offenbacher S. Periodontal diseases pathogenesis / S. Offenbacher // Amer. Periodontol. - 2013. - Vol. 1. P. 821-878.

5. Oguchi, Y. The nature of human blood group A3 erythrocytes. Vox. Sang., 34, 32-47.

6. Yamamoto, F. (1995). Molecular genetic of the AB0 histo-blood group system. Vox Sang., 69, 1-7.

7. Daniels, G.L., Anstee, D.J., \& Carton, J.P. (2005). Blood groups classification. Vox. Sang., 69 (4), 265-279.

8.Schenkel-Bruner, H. (2000). Human blood groups. Chemical and biochemical basis of antigen specificity. New York.

9.Anstee, D.J. (2013). Blood-group active surface molecules of the human red blood cell. Vox. Sang., 58, 1-20.

10. Ferreira, H.G., \& Lew, V.L. (2012). Membrane transport in red cell. Acad. Press. 
11. Daniels, G.L., Anstee, D.J., Carton, J.P. (1995). Blood groups classification. Vox Sang., 69 (4), 265-279.

12. Menshikov, V.V. (2002). Klinicheskaya laboratornaya analitika [Clinical laboratory analytics]. Moscow: AgatMed [in Russian].

13. Karpishchenko, A.I. (2013). Meditsinskiye laboratornyye tekhnologii [Medical laboratory technologies]. Moscow:GEOTAR-Media [in Russian].

14. Bennet, E., Steffensen, R., \& Clausen, H. (1995). Genomic cloning of the human histo-blood group AB0 locus. Biochem. Biophys. Res. Commun., 206, 318-325.

15. Bandrivskyi, Yu., Bandrivska, O., Gnid, R., Minko, L., \& Shevchuk M. (2019). Indicators of markers of bone metAB0lism in patients with generalized periodontitis depending on blood group affiliation: original paper. Arch. Balk Med. Union, 54 (1), 11-16.

16. Antonova, T.V., Nikolayenko, S.L., \& Lionozov, D.A. (1999). Znacheniye nekotorykh gematologicheskikh pokazateley pri ostrykh odontogennykh vospalitelnykh zabolevaniyakh chelyustey [The value of some hematological parameters in acute odontogenic inflammatory diseases of the jaw]. Klinicheskaya laboratornaya diagnostika - Clinical Laboratory Diagnostics, 7, 23-24 [in Russian].

17. Timofeyev, A.A. (2009). Znacheniye nekotorykh gematologicheskikh pokazateley pri ostrykh odontogennykh vospalitelnykh zabolevaniyakh chelyustey [The value of some hematological parameters in acute odontogenic inflammatory diseases of the jaw]. Probl. Allergii-Problems of Allergy, 6, 74-75 [in Russian]. 18.Stahl, S.S. (2010). Host resistance and periodontal diseases. J. Dent. Res., 49 (2), 248-255.

19. Danilevskiy, N.F., \& Borisenko, A.V. (2000). Zabolevaniya parodonta [Paradontium diseases]. Kyiv: Medytsyna [in Ukrainian].
20. Borysenko, A.V. (2008). Terapevtychna stomatolohiia [Therapeutic dentistry]. Kyiv: Medytsyna [in Ukrainian]. 21. Isacov, I., \& Levco, S. (2018). Preoperative assessment of patients with inflammatory processes in the maxillofacial region: a minireview. Arch. Balk Med. Union, 53 (2), 275-280

22. Palek, J., \& Sahr K.E. Red blood cell membrane mutations. Blood, 80, 308-330.

23. Nomura, Y., Tanaki, Y., \& Tanaka, T. (2006). Screening of periodontitis with salivary enzyme test. J. Oral Sral. Sci., 12, 177-183.

24. Grigoryan, A.S., Grudyanov, A.I., Ryabukhina, N.A., \& Frolova, O.A. Bolezni parodonta. Patogenez, diagnostika, lecheniye [Paradontium diseases. Pathogenesis, diagnostics, treatment]. Moscow: MIA [in Russian].

25. Fourel, J. (1972). Periodontosis: a periodontal syndrome. J. Periodontol., 43, 240-255.

26. Ostrovskiy, V.K., Mashchenko, A.B., \& Yangolenko, D.V. Pokazateli krovi i leykotsitarnogo indeksa intoksikatsii $\mathrm{v}$ otsenke tyazhesti i opredelenii prognoza pri vospalitelnykh gnoynykh i gnoynodestruktivnykh zabolevaniyakh [Blood counts and leukocyte intoxication index in assessing the severity and determination of the prognosis for inflammatory diseases]. Klinicheskaya laboratornaya diagnostika Clinical Laboratory Diagnostics, 50 [in Russian].

27. Bermeman, Z., van Bockstaele D., \& Uyttenbreek, W. (2013). Flow cytometric analysis of erythrocyte blood group A antigen density profiles. Vox. Sang., 61, 265-274. 28. Tomaszewski, T. (2012). Assessment of mandible bone structure in patients with generic osteoporosis symptoms. Annales Universitatis Mariae CurieSklodowska, 57, 329-341.

29. Offenbacher, S. (2013). Periodontal diseases pathogenesis. Amer. Periodontol., 1, 821-878.

Received 03.06.19 